\title{
Different photodynamic effects of blue light with and without riboflavin on methicillin-resistant Staphylococcus aureus (MRSA) and human keratinocytes in vitro
}

\author{
Karim Makdoumi ${ }^{1,2}$ (D) Marie Hedin ${ }^{3} \cdot$ Anders Bäckman $^{4}$
}

Received: 21 November 2018 / Accepted: 7 March 2019 / Published online: 30 March 2019

(C) The Author(s) 2019

\begin{abstract}
Methicillin-resistant Staphylococcus aureus (MRSA) is an important cause of infections in humans. Photodynamic therapy using blue light $(450 \mathrm{~nm})$ could possibly be used to reduce MRSA on different human tissue surfaces without killing the human cells. It could be less harmful than 300-400 nm light or common disinfectants. We applied blue light \pm riboflavin (RF) to MRSA and keratinocytes, in an in vitro liquid layer model, and compared the effect to elimination using common disinfection fluids. MRSA dilutions $\left(8 \times 10^{5} / \mathrm{mL}\right)$ in wells were exposed to blue light $(450 \mathrm{~nm}) \pm \mathrm{RF}$ at four separate doses $\left(15,30,56\right.$, and $\left.84 \mathrm{~J} / \mathrm{cm}^{2}\right)$. Treated samples were cultivated on blood agar plates and the colony forming units (CFU) determined. Adherent human cells were cultivated $\left(1 \times 10^{4} / \mathrm{mL}\right)$ and treated in the same way. The cell activity was then measured by Cell Titer Blue assay after 24and 48 -h growth. The tested disinfectants were chlorhexidine and hydrogen peroxide. Blue light alone $\left(84 \mathrm{~J} / \mathrm{cm}^{2}\right)$ eliminated $70 \%$ of MRSA. This dose and riboflavin eradicated $99-100 \%$ of MRSA. Keratinocytes were not affected by blue light alone at any dose. A dose of $30 \mathrm{~J} / \mathrm{cm}^{2}$ in riboflavin solution inactivated keratinocytes completely. Disinfectants inactivated all cells. Blue light alone at $450 \mathrm{~nm}$ can eliminate MRSA without inactivation of human keratinocytes. Hence, a high dose of blue light could perhaps be used to treat bacterial infections without loss of human skin cells. Photodynamic therapy using riboflavin and blue light should be explored further as it may perhaps be possible to exploit in treatment of skin diseases associated with keratinocyte hyperproliferation.
\end{abstract}

Keywords MRSA $\cdot$ Blue light $\cdot$ Photodynamic therapy $\cdot$ PDT $\cdot$ Keratinocytes $\cdot$ Riboflavin

\section{Introduction}

Methicillin-resistant Staphylococcus aureus (MRSA) is one of the most important bacterial pathogens associated with morbidity and mortality $[1,2]$. The development of new pharmacological

Karim Makdoumi

karim.makdoumi@regionorebrolan.se

1 Department of Ophthalmology, Faculty of Medicine and Health, Örebro University, Örebro, Sweden

2 Department of Ophthalmology, Örebro University Hospital, SE-701 85 Örebro, Sweden

3 Faculty of Medicine and Health, Örebro University, Örebro, Sweden

4 Department of Clinical Research Laboratory, Faculty of Medicine and Health, Örebro University, Örebro, Sweden agents is a complicated and slow process, with antibiotic resistance emerging as an increasing problem. Several approaches have been proposed to maintain the efficacy of currently available antimicrobials. These include educational efforts to reduce unnecessary prescription as well as infrastructural strategies to improve sanitation and limit spread of drug-resistant microorganisms. Furthermore, vaccines, probiotics, and more non-specific antimicrobials have been suggested as possible therapeutic strategies against infections [3-5].

Photodynamic therapy (PDT) or Photodynamic Antimicrobial Chemotherapy (PACT) is a mode of treatment which has been considered for local infections, and evaluated through in vitro and in vivo experiments [6,7]. Excitation of a photosensitizer by light illumination generates reactive oxygen species (ROS) which results in pathogen elimination [8-10]. However, blue light $(400-470 \mathrm{~nm})$ can eliminate both Gram-positive and Gram-negative bacteria without chromophores $[8,11]$ and is considered to be less harmful to human 
cells compared to UV irradiation $[8,12]$. It is believed that endogenous intracellular porphyrins are excited by blue light irradiation which functions as photosensitizers [13, 14]. Wavelengths between 402 and $420 \mathrm{~nm}$ are seemingly more effective than longer wavelength of blue light (455 and $470 \mathrm{~nm}$ ) although the longer wavelengths may have some advantages in elimination of dense bacterial cultures with high colony forming unit (CFU) counts [15-19]. Blue light in the lower wavelength spectrum (400-425 $\mathrm{nm}$ ) can be utilized to treat acne vulgaris with few side-effects reported [20-22].

Riboflavin (RF) (vitamin B2) is a non-toxic photosensitizer that can be used together with UV irradiation of blood components in order to eliminate microorganisms [23-26]. Combined with ultraviolet light $\mathrm{A}$, it is also clinically used in the treatment of corneal ectasia, such as keratokonus and has been evaluated in management of recalcitrant corneal infections [27]. We have previously investigated eradication of MRSA in vitro, mediated by riboflavin photoactivated using ultraviolet light A (365 nm) [28-30] and blue light (412 nm and $450 \mathrm{~nm})$ [31] in thin layers of fluid $(0.4-1.76 \mathrm{~mm})$. In these experiments, the elimination of blue light was augmented by the presence of riboflavin, and a relatively low dose was required to eliminate MRSA in a thin fluid-layer with the photosensitizer. In a thicker fluid-layer $(1.17 \mathrm{~mm})$, with higher number of bacteria, the effect (of $412 \mathrm{~nm}$ ) was reduced $(91 \%$ with riboflavin), which is consistent with other publications $[18,19]$ but the longer wavelength $(450 \mathrm{~nm})$ was not evaluated under these conditions.

It is possible that light with wavelength $450 \mathrm{~nm}$ is advantageous compared to $412 \mathrm{~nm}$ and could cause less damage to human cells but still be useful for inactivation of microorganisms. A higher dose of $450 \mathrm{~nm}$ would likely be required to mediate an antimicrobial effect in a thicker fluid layer and the impact on human cells must also be evaluated if this method should be considered for any in vivo application.

We therefore aimed to determine the effect of higher doses $\left(\geq 30 \mathrm{~J} / \mathrm{cm}^{2}\right)$ of blue light $(450 \mathrm{~nm})$ in a $1.2 \mathrm{~mm}$ fluid layer, with and without riboflavin for eradicating MRSA. Similarly, exposure was done on human keratinocytes as an indicator of effects of these dosages on human epithelial cells.

\section{Material and methods}

\section{Blue light source and exposure levels}

A prototype diode lamp (TERUMO.BCT, Lakewood, Colorado, USA) was used for irradiation, (Total Power Output $=7.14 \mathrm{~W}$, peak wavelength $=450 \mathrm{~nm}$ ) with three parallel light-emitting diodes (LedEngin, Inc., CA, USA) in a row spanning over $4.5 \mathrm{~cm}$, without light collimation, inside a square illumination box. Calibration was conducted prior to the experiments, on six different representative locations inside the illumination chamber to control adequate exposure of all wells (308 UV-intensity meter, OAI, CA, USA, $436 \mathrm{~nm}$ detector 308-0002-11). The defined irradiance was a mean of these six measurements. Bacterial and keratinocyte suspensions were treated with four different doses of $450 \mathrm{~nm}$ as measured at the fluid level in the experiment. Dose 1, $15 \mathrm{~J} /$ $\mathrm{cm}^{2}$ (irradiance $=25 \mathrm{~mW} / \mathrm{cm}^{2}$, time $=10 \mathrm{~min}$ ). Dose 2, $30 \mathrm{~J} /$ $\mathrm{cm}^{2}$ (irradiance $=25 \mathrm{~mW} / \mathrm{cm}^{2}$, time $=20 \mathrm{~min}$. Dose 3, $56 \mathrm{~J} /$ $\mathrm{cm}^{2}$, (irradiance $=46.6 \mathrm{~mW} / \mathrm{cm}^{2}$, time $=20 \mathrm{~min}$ ). Dose 4 , $84 \mathrm{~J} / \mathrm{cm}^{2}$ (irradiance $=46.6 \mathrm{~mW} / \mathrm{cm}^{2}$, time $=30 \mathrm{~min}$ ). The distance to the LED-lamps was $13 \mathrm{~cm}$ for the two lower doses and $9 \mathrm{~cm}$ for the higher light exposure. The exposed area evaluated during illumination was $16.25 \mathrm{~cm}^{2}$.

\section{MRSA reduction after light exposure}

Staphylococcus aureus resistant to methicillin and oxacillin (MRSA) (American Type Culture Collection (ATCC) no. 43300), stored at $-80^{\circ} \mathrm{C}$ and cultured at $37{ }^{\circ} \mathrm{C}$, was obtained from colonies on blood agar plates. The bacteria were counted in a Bürker Chamber and diluted in sterile phosphate buffered saline (PBS) (no: 14190-094, Gibco by Life Technologies, Life Technologies Corp., Paisley,UK) to approximately $4 \times$ $10^{6} \mathrm{CFU} / \mathrm{mL}$. Further dilution was made using cell culture medium (RPMI, Gibco no: 11835-063) with and without addition of riboflavin (RF), final concentration in suspensions 0.01\% (no. R7649-25G, SIGMA-Aldrich, Schnelldorf, Germany). The estimated CFU/mL concentration in solutions was $8 \times 10^{5} \mathrm{CFU} / \mathrm{mL}$ at the start of experiments.

Bacterial mixtures were placed in specific wells $(n=3)$ on cell culture plates $(40 \mu \mathrm{L}$ per well, $6.5 \mathrm{~mm}$ diameter, fluid thickness $1.2 \mathrm{~mm}$ ) (Sarstedt 96 well plate, no: 83.3924.500, SARSTEDT AG \& Co., Numbrecht, Germany) positioned directly below light source to allow exposure of the entire well. One plate was illuminated with $450 \mathrm{~nm}$; the other was kept distanced in darkness within the same room during the exposure time to avoid photosensitization from lamp as well as from background light.

A sample $(10 \mu \mathrm{L})$ was taken from each well and plate after treatment, diluted with PBS and $50 \mu \mathrm{L}$ of this dilution was spread with Z-rod on blood agar plates. The blood agar plates were cultured overnight at $37^{\circ} \mathrm{C}$. Colonies were counted manually and the number colony forming units (CFU) was determined. The complete experiments were repeated two or three times. Most CFU counts were controlled by two independent examiners.

In order to facilitate comparisons with results from our previous study with blue light evaluation [31], a modified thin layer-model was also used as previously described [29]. By using $20 \mu \mathrm{L}$ volume of bacterial dispersion, forming a $0.5 \mathrm{~mm}$ layer on adhesive sterile preparation glass wells, evaluation of MRSA elimination in fluid films was conducted twice. Light exposure with $450 \mathrm{~nm}$ was done (irradiance $25 \mathrm{~mW} / \mathrm{cm}^{2}$, 
$13 \mathrm{~cm}$ from LED) with and without presence of RF $(0.01 \%)$ at doses of 10,15 , and $30 \mathrm{~J} / \mathrm{cm}^{2}$. Samples of $5 \mu \mathrm{L}$ were withdrawn from the wells $(n=4)$ for CFU-determination. A different source of riboflavin was used in these experiments (sterile $500 \mu \mathrm{M}$ riboflavin in $0.9 \% \mathrm{NaCl}$, (Terumo BCT, USA). Dilution in RPMI was done to reach a riboflavin concentration of $0.01 \%$.

\section{Keratinocyte inactivation after light exposure}

Immortalized human keratinocytes (HaCat) (no. 300493, Cell Lines Service (CLS) GmbH, Eppelheim, Germany) from stocks in liquid nitrogen, were cultivated $\left(37{ }^{\circ} \mathrm{C}\right.$, $5 \% \mathrm{CO}_{2}$ ) (DMEM, Gibco no. 61965-026), with $10 \%$ fetal bovine serum (Gibco, no. 10270) and $0.1 \%$ gentamicin (Gibco, no. 15710-049) using a T-75-bottle (Sarstedt, no: 833911002). 70-80\% confluent cells were trypsinated (Sigma, no. T 3924) and diluted in cell culture medium with a concentration of approximately 50,000 cells $/ \mathrm{mL}$ (passages 12, 14, and 16 at the time for the experiment). The cell solution $(100 \mu \mathrm{L})$ was placed in each of the six wells in the center of two cell culture plates (Sarstedt 96 well, no. 83.3924.500).

After 2 days of incubation, there were approximately $1 \times 10^{4}$ viable cells in every well and the experiments were performed. For every experiment, the cell culture medium was removed from the wells and replaced with (sterile) $40 \mu \mathrm{L}$ RPMI, \pm RF $(0.01 \%$ ) (SIGMA, no. R 7649$25 \mathrm{G})$. One of the plates was exposed to $450 \mathrm{~nm}$ and the other was kept under dark conditions during the exposure time, in the same room as the exposed solutions. After, the irradiation solutions in all wells were removed and the cells were washed once with $100 \mu \mathrm{L}$ cell culture medium. The measurement of cell activity after incubation for $24 \mathrm{~h}$ and $48 \mathrm{~h}$ was performed as separate experiments. Cell Titer-Blue mixture (CTB, no. G808A, Promega Biotech AB, Sweden) $(20 \mu \mathrm{L})$ was added to the $100 \mu \mathrm{L}$ medium above the keratinocyte cell layer on the plates. These were then incubated for $2 \mathrm{~h}\left(37{ }^{\circ} \mathrm{C}, 5 \% \mathrm{CO}_{2}\right)$ to assess keratinocyte ability to break down the blue pigment (resazurin) into a fluorescent end product (resorufin). The mixture in the wells $(100 \mu \mathrm{L})$ was removed to a black-walled reading plate (no. 655090, Greiner bio-one $\mathrm{GmbH}$, Frickenhausen, Germany) and relative fluorescence was measured in FLUO star OPTIMA) (excitation at $544 \mathrm{~nm}$ and emission at $590 \mathrm{~nm}$ ), using the supplied software (BMG Lab technologies BmbH, Offenburg, Germany). This was repeated for all doses and controls in the experiment. The results were compared to negative controls (CTB and cell culture medium and/or cell culture medium only), and corrected for background signal. These experiments were repeated in full three times during three different weeks.

\section{Effect of disinfection solutions on MRSA}

To evaluate skin surface disinfection fluids' effect on MRSA compared to blue light exposure, bacterial solutions $(40 \mu \mathrm{L})$ (estimated $8 \times 10^{5}$ bacteria $/ \mathrm{mL}$ in RPMI) without RF were mixed with equal amount of disinfectant; hydrogen peroxide 3\% (HPO) (no. 331926, Apotek produktion \& laboratorier $\mathrm{AB}$, Sweden) or chlorhexidine $0.5 \mathrm{mg} / \mathrm{mL}$ (CHX) (no. 549550, Fresenius Kabi AB, Sweden). A desiccating skin wash solution, aluminum acetotartrate solution $10 \mathrm{mg} / \mathrm{mL}$ (Alsol) (no. 207634, Apoteket AB, Sweden), was also tested. After incubation of the plates in darkness for 1, 2, 5, 10, and $15 \mathrm{~min}, 10 \mu \mathrm{L}$ was removed from each well and CFU was established as described before. The results were compared to the start concentration of control wells.

\section{Effect of disinfection solutions on keratinocytes}

Surface disinfection solutions were also evaluated on keratinocytes. After preparation and incubation of HaCat cells, as specified above, the cell culture medium was removed from the wells on two separate plates. Subsequently, $40 \mu \mathrm{L}$ of RPMI was mixed with the same volume of epidermal washing fluid (the three types specified above) and added to the wells. Incubation was done for 1, 2, 5, 10, 15, and $20 \mathrm{~min}$. The suspensions were removed, the keratinocytes washed once with $100 \mu \mathrm{l}$ cell culture medium, and incubated for $48 \mathrm{~h}$. Cell viability was measured as described previously.

\section{Statistical analysis}

Values were expressed as means \pm standard deviations. Relevant comparisons of ratios were analyzed using the nonparametric Mann-Whitney U-test (two-tailed) for independent samples without the assumption of normal distribution. Calculations made by using IBM ${ }^{\circ}$ SPSS $®$ Statistics 22.0 for Windows (IBM Corp., Armonk, NY, USA) were used for analysis and $p$ values below 0.05 were considered statistically significant.

\section{Results}

Elimination of MRSA by blue light was, at all dosages, potentiated by the presence of riboflavin (RF) (Fig. 1). At lower irradiation settings $\left(15 \mathrm{~J} / \mathrm{cm}^{2}\right.$ and $\left.30 \mathrm{~J} / \mathrm{cm}^{2}\right)$, light alone did not decrease the number of bacteria in suspension significantly. Blue light exposure together with riboflavin $(+\mathrm{RF})$ reduced the mean number of CFU significantly ( $p$ value ranging between $<0.001$ and 0.009 ) at all dosages compared to nonilluminated solutions $(-\mathrm{RF})$. The elimination of MRSA was more pronounced at higher light dosage, with $57 \%$ reduction at dose 1 , reaching $99.5 \%$ at dose 4 . Riboflavin without 


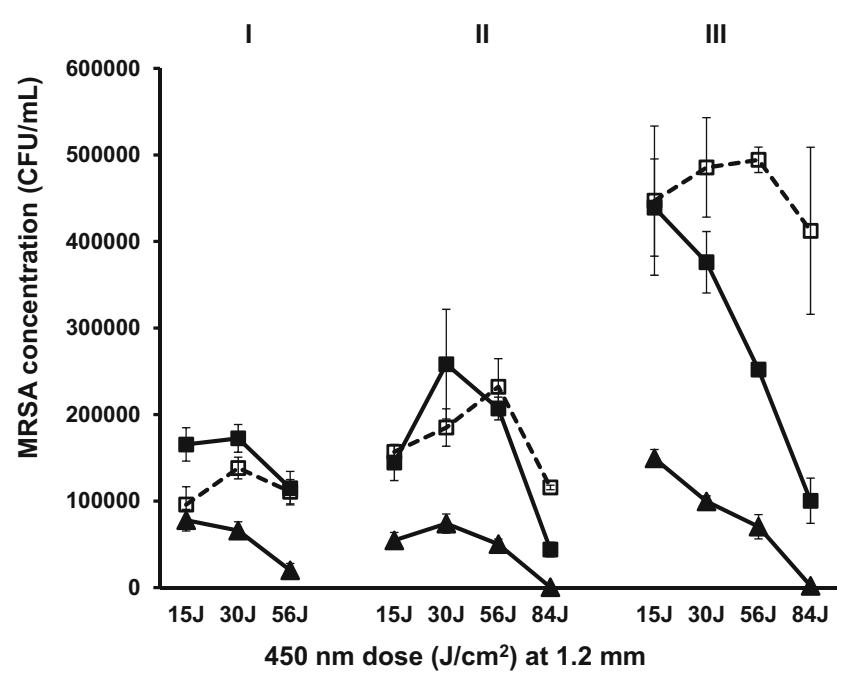

Fig. 1 The effect on MRSA concentration (colony forming units (CFU)) after treatment with $450 \mathrm{~nm}$ with riboflavin (Sigma) (filled triangle), or without riboflavin (filled squares) in a $1.2-\mathrm{mm}$ liquid layer in three separate experiments (I, II, and III). Results were compared to separate negative controls: blue light and riboflavin (empty squares). Data shown as the mean concentration of MRSA \pm standard deviation for each experimental point $(n=3)$

illumination exposure did not influence growth of bacteria significantly. Blue light exposure without a photosensitizer led to a statistically significant decrease of bacteria compared to controls, only at the two higher evaluated levels (dose 3 and $4)$, with $41 \%(p=0.012)$, and $71 \%$ reduction $(p=0.006)$, respectively (Fig. 1). The difference in bacterial elimination between blue light with and without RF $(0.01 \%)$ at the highest exposure level $\left(84 \mathrm{~J} / \mathrm{cm}^{2}\right)$ was statistically significant $(p=$ 0.004). Irradiation of MRSA using blue light with riboflavin $(+\mathrm{RF})$ in the thinner fluid layer $(0.5 \mathrm{~mm})$ required a dose of $30 \mathrm{~J} / \mathrm{cm}^{2}$ for complete eradication (Fig. 2) and the same exposure dose alone $(-\mathrm{RF})$ reduced MRSA in fluid by $50 \%$ ( $p=$ 0.007). Keratinocytes exposed to blue light solitarily were not affected significantly at any tested dose, as detected by CTBassay after $24 \mathrm{~h}$ (not shown) and $48 \mathrm{~h}$ (Fig. 3). Irradiation of cells in the presence of riboflavin resulted in a nearly complete inactivation at a dose of $30 \mathrm{~J} / \mathrm{cm}^{2}$ and above after $48 \mathrm{~h}$.

The control experiments showed that the two disinfectants eradicated all MRSA after $5 \mathrm{~min}$, however, the aluminum acetotartrate wash solution (Alsol) reduced the CFU number in solutions but did not eliminate all bacteria, even after $15 \mathrm{~min}$ of incubation (Fig. 4). All disinfectant resulted in complete keratinocyte inactivation, in CTB measurement and took place within 2 min after exposure (Fig. 5). The 24-h measurements as well as extended viability measurements are not shown.

\section{Discussion}

Blue light alone at $450 \mathrm{~nm}\left(84 \mathrm{~J} / \mathrm{cm}^{2}\right)$ reduced the number of MRSA by approximately $70 \%$ without inactivation of human

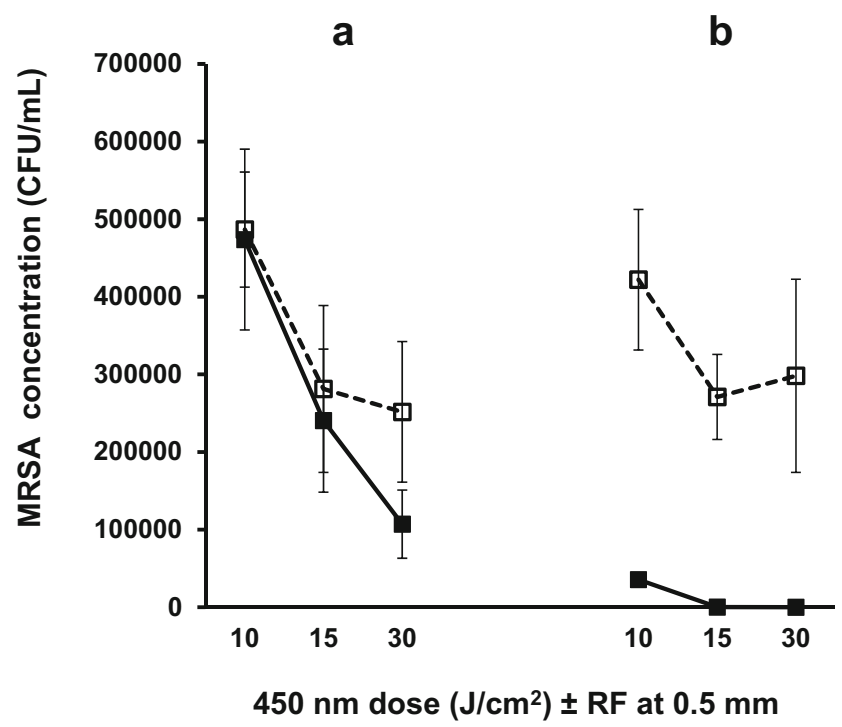

Fig. 2 The effect on MRSA concentration (colony forming units (CFU)) after treatment with $450 \mathrm{~nm}$ (filled squares), without (A) and with riboflavin (RF) (B) (Terumo) in a thinner fluid-layer $(0.5 \mathrm{~mm})$ as compared to negative blue light controls (empty squares). Data shown as the mean concentration of MRSA \pm standard deviation $(n=7-8)$

keratinocytes in the 1.2-mm fluid layer. Higher exposure doses would likely result in a more extensive elimination of bacteria, as seen by the trend in elimination. The effect would probably be higher in a thinner fluid layer, as seen by the $50 \%$ reduction using $30 \mathrm{~J} / \mathrm{cm}^{2}$, which in the $1.2-\mathrm{mm}$ layer would correspond to the blue light effect of $56 \mathrm{~J} / \mathrm{cm}^{2}$ (53\% reduction) (Fig. 1). Our results are in line with several other studies evaluating the antimicrobial effect of blue light on MRSA [15, 16, $18,19,22,32]$. Previous experimental studies have shown

a b

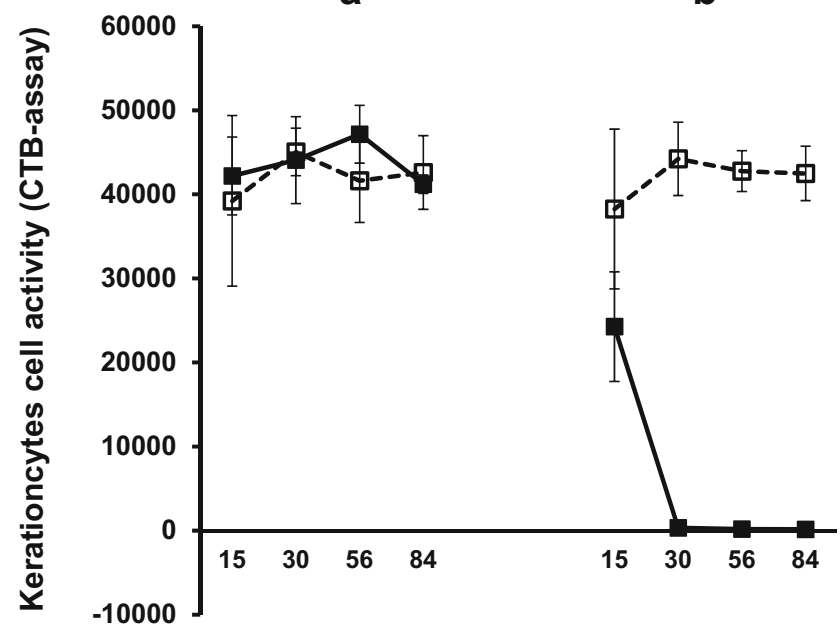

$450 \mathrm{~nm}$ Dose $\left(\mathrm{J} / \mathrm{cm}^{2}\right) \pm R F$ at $1.2 \mathrm{~mm}$

Fig. 3 The effect on keratinocyte cell activity (Cell Titer Blue-assay (CTB)) in culture wells, $48 \mathrm{~h}$ after treatment with $450 \mathrm{~nm}$ (filled squares), without (A) and with (B) riboflavin (RF) (Sigma) in a 1.2-mm liquid layer as compared to negative controls (empty squares). Data shown as means \pm standard deviations $(n=9)$ 


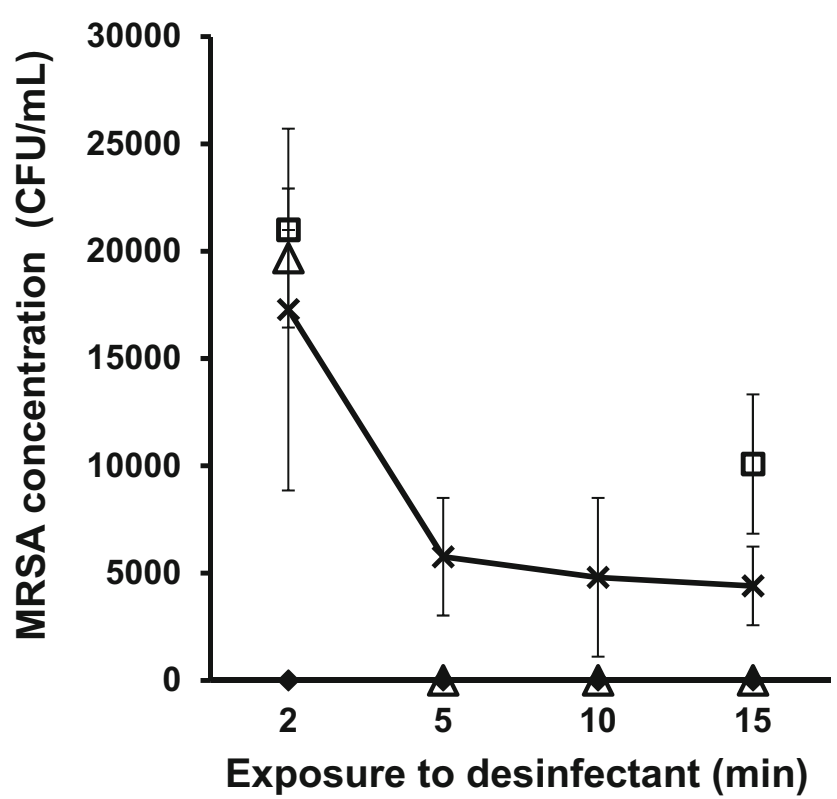

Fig. 4 The reduction of MRSA when suspensions were mixed with equal volume $(40 \mu \mathrm{L})$ of fluid surface disinfectants and exposed for $2-15 \mathrm{~min}$. The tested disinfectants were chlorhexidine (filled diamond), Alsol (Aluminum acetotartrate solution) (Cross), and hydrogen peroxide (empty triangle). The results ( $n=5$ for 2-10 min exposure and $n=3$ for $15 \mathrm{~min}$ exposure) were compared to untreated negative controls (empty squares) at $2 \min (n=1)$ and after $15 \min (n=5)$. Data shown as means \pm standard deviations

more or less efficient elimination but it is difficult to make direct comparisons of efficacy between these due to methodological differences. Several publications have evaluated effects on MRSA exposed on agar plates directly but some

a b c

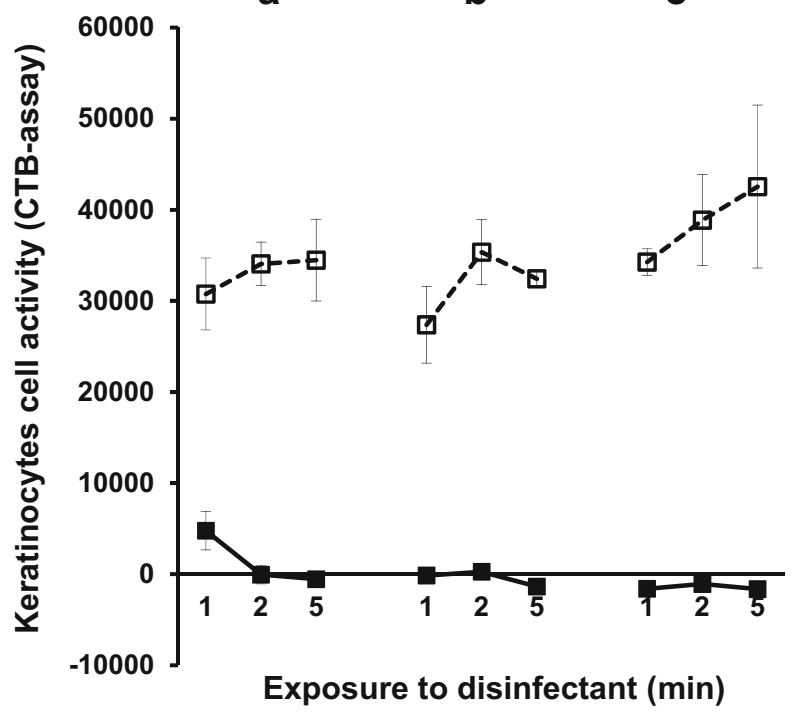

Fig. 5 The effect on keratinocyte cell activity (Cell Titer Blue-assay (CTB)) in culture wells, $48 \mathrm{~h}$ after treatment (filled square) (1-5 min) with RPMI solution $(40 \mu \mathrm{L})$ and equal volume of disinfection fluids, chlorhexidine (A), Alsol (Aluminum acetotartrate solution) (B), and hydrogen peroxide (C). Results were compared to untreated controls (empty square). Data shown as means \pm standard deviations $(n=3)$ advantages with our model, using bacterial suspensions, is that it facilitates an exact control of photosensitizer concentration in the fluid as well as assessment of reduction in bacterial number. However, several aspects involved need to be investigated to more completely elucidate underlying mechanisms mediating the riboflavin-mediated photodynamic cell inactivation. Some of these are study of bacterial biofilms, intracellular mechanism, and measurement of ROS-levels induced by the photodynamic treatment.

Keratinocytes were not affected by blue light exposure alone, at any dose evaluated. However, illumination in combination with riboflavin inactivated these cells already at a dose of $30 \mathrm{~J} / \mathrm{cm}^{2}$. Hence, human keratinocytes in these experiments responded differently than bacterial cells towards the photooxidative stress generated by riboflavin photosensitization compared to blue light exposure alone. Perhaps the dissimilar outcome can in part be explained by differences in method used for evaluation (HaCat adherent cells and MRSA in suspension) and the number of cells in suspensions. Moreover, the assay used for cell activity examines only one aspect of cellular life processes and the effects were only followed $48 \mathrm{~h}$ after illumination. The immediate effect was however clearly different between bacteria and the immortalized human cell line. Since the photodynamic approach, using blue light and riboflavin, as well as disinfectants influenced keratinocytes strongly, the former could be advantageous in certain situations in which a more selective antimicrobial effect is desired. Some examples are elimination of bacteria in biofilms, mucus membranes, and on skin wounds without affecting human cells detrimentally. Light exposure can be controlled; however, loss of keratinocytes in vivo is to be expected in possible treatment of a skin or wound infection. Other publications have reported keratinocyte cytotoxicity in vitro after blue light with wavelengths between 412 and $426 \mathrm{~nm}$ at dosages between 66 and $100 \mathrm{~J} / \mathrm{cm}^{2}$ with reported cytotoxicity limit for $453 \mathrm{~nm}$ light at considerably higher levels [22, 33].

In these experiments, we showed that riboflavin enhances the antibacterial efficacy of blue light exposure. The highest evaluated dose $\left(84 \mathrm{~J} / \mathrm{cm}^{2}\right)$ of 450 -nm light with riboflavin in $1.2 \mathrm{~mm}$ thickness resulted in a nearly complete elimination of bacteria. As expected, the effect increased with higher light dosage and was at all dosages superior in the presence of riboflavin. However, a greater light dose was needed for elimination compared to $412 \mathrm{~nm}$ light, which was studied in our previous study with MRSA using a similar fluid layer thickness [31]. These results indicate that more light intensity or exposure time is required using $450 \mathrm{~nm}$ than for $412 \mathrm{~nm}$ light. Based on previous experiments, we decided only to evaluate one riboflavin concentration, since only a low quantity of the photosensitizer is required for pathogen elimination $[28,30]$. However, it is possible that increased dose exposure would perhaps require higher concentration for optimized 
elimination. Hence, further studies on blue light-mediated photodynamic inactivation of microorganisms with different irradiation settings and pathogens are warranted. However, the results may at least in part be a consequence of the fact that the mean bacterial concentration was roughly ten times higher in the current experiments compared to our previous study. In other aspects, the experimental settings were almost identical.

Since the effect of riboflavin photosensitization was relatively distinct, and seemingly more pronounced than in MRSA, it is possible that photodynamic therapy by blue light and riboflavin is possible to exploit for treatment of skin conditions associated with hyperproliferative keratinocytes such as psoriasis [34] or atopic dermatitis [35]. Riboflavin is from many perspectives an ideal photosensitizer, given that it is present in human cells, with non-toxic degradation products and already clinically applicable in photodynamic use of human tissue. Riboflavin-mediated pathogen eradication of blood products is already currently used in blood transfusions and riboflavin is tolerated in high dosages for prevention of migraines in human without any indications of toxicity [36]. One example of the documented in vivo implementation photochemical effect of riboflavin is corneal crosslinking (CXL) $[37,38]$ for treatment of keratoconus and other corneal ectasia. Since shortwave ultraviolet light (UVB) is hazardous to genetic material and could potentially be carcinogenic [39], blue light applied as a photodynamic treatment could be preferable to phototherapy using UVB. Another possible advantage of combining phototherapy with a photosensitizer, if applied similarly as in ocular use, is the control of exposed area given that riboflavin is needed for the photodynamic effect. Recently, photodynamic therapy was proposed for treatment of psoriasis $[40,41]$ but, to our knowledge, this is the first study that has suggested a possible use for riboflavin photoactivation for the condition.

The control experiments using surface disinfection fluids on MRSA showed expected results, with regard to antimicrobial efficacy. However, the skin-wash solution containing aluminum acetotartrate (Alsol) did not eradicate all MRSA after 20 min incubation time, which is remarkably long, indicating that it is not an efficient disinfectant. All the tested fluids were surprisingly effective with regard to inactivation of keratinocytes, observed already after 1-2 min. This could indicate a prominent effect on keratinocytes when applying conventional disinfection fluids in vivo, if applied in such a way that keratinocytes are directly exposed.

\section{Conclusion}

Blue light with riboflavin can, in a fluid layer of $1.2 \mathrm{~mm}$, effectively eradicate MRSA and inactivate human keratinocytes. In the absence of a photosensitizer, $450 \mathrm{~nm}$ light can also eliminate bacteria without loss of skin cell viability. A high dose of blue light may possibly be used to inactivate bacteria without the identical effect in human cells in sterilization of bacteria in biofilms, on tissue mucus membranes, and superficial skin wounds. Photodynamic therapy, through riboflavin excitation by blue light, may perhaps also be useful for conditions associated with hyperproliferative keratinocytes, such as psoriasis and atopic dermatitis. Future studies are needed to investigate these findings before in vivo applicability is possible.

Acknowledgments Many thanks to Professor Ray Goodrich, Colorado State University, and Terumo BCT for supplying the 450-nm prototype lamp and some of the riboflavin solutions used in the experiments. Thanks also to medical student Annam Cheema for helping with some of the control experiments.

Funding information The work was funded by Örebro University and Örebro University Hospital (Sweden) Research Funds, D-number 461291.

\section{Compliance with ethical standards}

Conflict of interest The authors declare that they have no conflict of interest.

Ethical approval All cells used in experiments were commercial reference strains, MRSA (ATCC 43300) and keratinocytes (HaCat 300493, Cell Lines Service (CLS) GmbH, Eppelheim, Germany). Hence, no requirement for ethical approval was needed.

Open Access This article is distributed under the terms of the Creative Commons Attribution 4.0 International License (http:// creativecommons.org/licenses/by/4.0/), which permits unrestricted use, distribution, and reproduction in any medium, provided you give appropriate credit to the original author(s) and the source, provide a link to the Creative Commons license, and indicate if changes were made.

\section{References}

1. DeLeo FR, Otto M, Kreiswirth BN, Chambers HF (2010) Community-associated meticillin-resistant Staphylococcus aureus. Lancet 375:1557-1568

2. Ventola CL (2015) The antibiotic resistance crisis: part 1: causes and threats. P T 40:277-283

3. Morell EA, Balkin DM (2010) Methicillin-resistant Staphylococcus aureus: a pervasive pathogen highlights the need for new antimicrobial development. Yale J Biol Med 83:223-233

4. Bush K, Courvalin P, Dantas G, Davies J, Eisenstein B, Huovinen P, Jacoby GA, Kishony R, Kreiswirth BN, Kutter E, Lerner SA, Levy S, Lewis K, Lomovskaya O, Miller JH, Mobashery S, Piddock LJ, Projan S, Thomas CM, Tomasz A, Tulkens PM, Walsh TR, Watson JD, Witkowski J, Witte W, Wright G, Yeh P, Zgurskaya HI (2011) Tackling antibiotic resistance. Nat Rev Microbiol 9:894-896

5. Septimus EJ, Schweizer ML (2016) Decolonization in prevention of health care-associated infections. Clin Microbiol Rev 29:201222 
6. Dai T, Huang YY, Hamblin MR (2009) Photodynamic therapy for localized infections-state of the art. Photodiagn Photodyn Ther 6: $170-188$

7. Jori G, Fabris C, Soncin M, Ferro S, Coppellotti O, Dei D, Fantetti L, Chiti G, Roncucci G (2006) Photodynamic therapy in the treatment of microbial infections: basic principles and perspective applications. Lasers Surg Med 38:468-481

8. Yin R, Dai T, Avci P, Jorge AE, de Melo WC, Vecchio D, Huang YY, Gupta A, Hamblin MR (2013) Light based anti-infectives: ultraviolet $\mathrm{C}$ irradiation, photodynamic therapy, blue light, and beyond. Curr Opin Pharmacol 13:731-762

9. Baltazar LM, Ray A, Santos DA, Cisalpino PS, Friedman AJ, Nosanchuk JD (2015) Antimicrobial photodynamic therapy: an effective alternative approach to control fungal infections. Front Microbiol 6:202

10. Perez-Laguna V, Perez-Artiaga L, Lampaya-Perez V, Garcia-Luque I, Ballesta S, Nonell S, Paz-Cristobal MP, Gilaberte Y, Rezusta A (2017) Bactericidal effect of photodynamic therapy, alone or in combination with mupirocin or linezolid, on Staphylococcus aureus. Front Microbiol 8:1002

11. McKenzie K, Maclean M, Grant MH, Ramakrishnan P, MacGregor SJ, Anderson JG (2016) The effects of $405 \mathrm{~nm}$ light on bacterial membrane integrity determined by salt and bile tolerance assays, leakage of UV-absorbing material and SYTOX green labelling. Microbiology 162:1680-1688

12. Kleinpenning MM, Smits T, Frunt MH, van Erp PE, van de Kerkhof PC, Gerritsen RM (2010) Clinical and histological effects of blue light on normal skin. Photodermatol Photoimmunol Photomed 26:16-21

13. Maclean M, Macgregor SJ, Anderson JG, Woolsey GA (2008) The role of oxygen in the visible-light inactivation of Staphylococcus aureus. J Photochem Photobiol B 92:180-184

14. Hamblin MR, Viveiros J, Yang C, Ahmadi A, Ganz RA, Tolkoff MJ (2005) Helicobacter pylori accumulates photoactive porphyrins and is killed by visible light. Antimicrob Agents Chemother 49: 2822-2827

15. Enwemeka CS, Williams D, Enwemeka SK, Hollosi S, Yens D (2009) Blue 470-nm light kills methicillin-resistant Staphylococcus aureus (MRSA) in vitro. Photomed Laser Surg 27:221-226

16. Enwemeka CS, Williams D, Hollosi S, Yens D, Enwemeka SK (2008) Visible $405 \mathrm{~nm}$ SLD light photo-destroys methicillin-resistant Staphylococcus aureus (MRSA) in vitro. Lasers Surg Med 40: 734-737

17. Guffey JS, Wilborn J (2006) In vitro bactericidal effects of 405-nm and 470-nm blue light. Photomed Laser Surg 24:684-688

18. Bumah VV, Masson-Meyers DS, Cashin SE, Enwemeka CS (2013) Wavelength and bacterial density influence the bactericidal effect of blue light on methicillin-resistant Staphylococcus aureus (MRSA). Photomed Laser Surg 31:547-553

19. Bumah VV, Masson-Meyers DS, Cashin S, Enwemeka CS (2015) Optimization of the antimicrobial effect of blue light on methicillinresistant Staphylococcus aureus (MRSA) in vitro. Lasers Surg Med 47:266-272

20. Das S, Reynolds RV (2014) Recent advances in acne pathogenesis: implications for therapy. Am J Clin Dermatol 15:479-488

21. Ammad S, Gonzales M, Edwards C, Finlay AY, Mills C (2008) An assessment of the efficacy of blue light phototherapy in the treatment of acne vulgaris. J Cosmet Dermatol 7:180-188

22. Dai T, Gupta A, Murray CK, Vrahas MS, Tegos GP, Hamblin MR (2012) Blue light for infectious diseases: Propionibacterium acnes, Helicobacter pylori, and beyond? Drug Resist Updat 15:223-236

23. Wainwright M, Baptista MS (2011) The application of photosensitisers to tropical pathogens in the blood supply. Photodiagn Photodyn Ther 8:240-248
24. Kwon SY, Kim IS, Bae JE, Kang JW, Cho YJ, Cho NS, Lee SW (2014) Pathogen inactivation efficacy of Mirasol PRT system and intercept blood system for non-leucoreduced platelet-rich plasmaderived platelets suspended in plasma. Vox Sang 107:254-260

25. Keil SD, Saakadze N, Bowen R, Newman JL, Karatela S, Gordy P, Marschner S, Roback J, Hillyer CD (2015) Riboflavin and ultraviolet light for pathogen reduction of murine cytomegalovirus in blood products. Transfusion (Paris) 55:858-863

26. Choi R, Kim S, Yoo H, Cho YY, Kim SW, Chung JH, Oh S, Lee SY (2015) High prevalence of vitamin D deficiency in pregnant Korean women: the first trimester and the winter season as risk factors for vitamin D deficiency. Nutrients 7:3427-3448

27. Chan TC, Lau TW, Lee JW (2015) Corneal collagen cross-linking for infectious keratitis: an update of clinical studies, vol 93, pp 689696

28. Backman A, Makdoumi K, Mortensen J, Crafoord S (2014) The efficiency of cross-linking methods in eradication of bacteria is influenced by the riboflavin concentration and the irradiation time of ultraviolet light. Acta Ophthalmol 92:656-661

29. Makdoumi K, Backman A (2016) Photodynamic UVA-riboflavin bacterial elimination in antibiotic-resistant bacteria. Clin Exp Ophthalmol 44:582-586

30. Makdoumi K, Backman A, Mortensen J, Crafoord S (2010) Evaluation of antibacterial efficacy of photo-activated riboflavin using ultraviolet light (UVA). Graefes Arch Clin Exp Ophthalmol 248:207-212

31. Makdoumi K, Goodrich R, Backman A (2017) Photochemical eradication of methicillin-resistant Staphylococcus aureus by blue light activation of riboflavin. Acta Ophthalmol 95:498-502

32. Lipovsky A, Nitzan Y, Gedanken A, Lubart R (2010) Visible lightinduced killing of bacteria as a function of wavelength: implication for wound healing. Lasers Surg Med 42:467-472

33. Liebmann J, Born M, Kolb-Bachofen V (2010) Blue-light irradiation regulates proliferation and differentiation in human skin cells. $\mathrm{J}$ Invest Dermatol 130:259-269

34. Wang MJ, Xu YY, Huang RY, Chen XM, Chen HM, Han L, Yan YH, Lu CJ (2017) Role of an imbalanced miRNAs axis in pathogenesis of psoriasis: novel perspectives based on review of the literature. Oncotarget 8:5498-5507

35. Ortiz-Salvador JM, Perez-Ferriols A (2017) Phototherapy in atopic dermatitis. Adv Exp Med Biol 996:279-286

36. Marashly ET, Bohlega SA (2017) Riboflavin has neuroprotective potential: focus on Parkinson's disease and migraine. Front Neurol $8: 333$

37. Li J, Ji P, Lin X (2015) Efficacy of corneal collagen cross-linking for treatment of keratoconus: a meta-analysis of randomized controlled trials. PLoS One 10:e127079

38. Kobashi H, Rong SS (2017) Corneal collagen cross-linking for keratoconus: systematic review. Biomed Res Int 2017:8145651

39. Nishisgori C (2015) Current concept of photocarcinogenesis. Photochem Photobiol Sci 14:1713-1721

40. Wang XL, Sun Q (2017) Photodynamic therapy with 5aminolevulinic acid suppresses IFN-gamma-induced K17 expression in $\mathrm{HaCaT}$ cells via MAPK pathway. Eur Rev Med Pharmacol Sci 21:4694-4702

41. Liu HQ, Wang YM, Li WF, Li C, Jiang ZH, Bao J, Wei JF, Jin HT, Wang AP (2017) Anti-psoriasis effects and mechanisms of alpha(8-quinolinoxy) zinc phthalocyanine-mediated photodynamic therapy. Cell Physiol Biochem 44:200-214

Publisher's note Springer Nature remains neutral with regard to jurisdictional claims in published maps and institutional affiliations. 